\title{
How to reconcile Environmental and Economic Performance to improve Corporate Sustainability: Corporate Environmental Strategies in the
} European Paper Industry

\author{
Marcus Wagner, Center for Sustainability Management, University of Lüneburg, Germany \\ 21335 Lüneburg, E-mail: mwagner@uni-lueneburg.de, Fax +49 (0) 89 6279-2952
}

\begin{abstract}
The paper discusses the relationship between environmental and economic performance and the influence of corporate strategies with regard sustainability and the environment. After formulating a theoretical model, results are reported from an empirical analysis of the European paper manufacturing industry. It uses new data to test hypotheses derived from the theoretical model, using environmental performance indices representing different corporate environmental strategy orientations. In particular, an emissions-based index largely reflecting end-of-pipe strategies and an inputs-based index reflecting integrated pollution prevention are distinguished. For the emissions-based index, a predominantly negative relationship between environmental and economic performance is found, whereas for the inputs-based index no significant link is found. This is consistent with the theoretical model, which predicts the possibility of different relationships. The results also show that for firms with pollution prevention-oriented corporate environmental strategies, the relationship between environmental and economic performance is more positive, thus making improvements of corporate sustainability more likely. Based on this last insight, managerial implications of this are discussed with regard to strategy choices, investment decisions and operations management.
\end{abstract}

Keywords: relationship, environmental, economic, performance, econometric, panel, analysis, paper, industry, Europe, corporate, strategy

Appeared in:

Wagner, M. (2005). How to reconcile environmental and economic performance to improve corporate sustainability: corporate environmental strategies in the European paper industry. Journal of Environmental Management, 76(2), 105-118. 


\section{Introduction: A theoretical model of the relationship of environmental and economic performance at the firm level and the influence of strategy choice}

The longer-term relationship between environmental performance and economic performance (in terms of both financial/accounting ratios and market-based measures, has been studied for over a decade with a more detailed review of this body of literature provided by e.g. Wagner (2001). Whilst earlier studies are based on both univariate (e.g. Jaggi and Freedman 1992; Cohen et al. 1995) as well as multivariate (e.g. Cormier et al. 1993; Cormier and Magnan 1997) analysis, more recent studies apply multivariate techniques (e.g. Cohen et al. 1995; Konar and Cohen 2001, Ziegler et al. 2002) up to the point of using panel models (e.g. King and Lenox 2001) and simultaneous equations approaches (e.g. Al-Tuwaijri et al. 2004). Next to econometric analyses with a longer-term time horizon, the short-term relationship between environmental and economic performance is analysed on the basis of so-called event studies, some of which also analyse the effect of environmental disclosure on the short-term influence of environmental on economic performance (e.g. Blacconiere and Patten 1994). The study which is reported in this paper analyses the longer-term relationship of environmental and economic performance based on multivariate regression analysis making use of (fixed and random effects) panel models. This is to overcome the deficiencies of univariate techniques and take into account the panel structure of the data.

The objective of this research is to establish the relationship between the environmental performance and economic performance at the firm level in the European Union (EU), based on an analysis of companies in one specific industrial sector in four EU countries. This industrial sector chosen for analysis is the pulp and paper industry. ${ }^{1}$ The countries in which firms in this sector are analysed are Germany, Italy, the Netherlands and the United Kingdom of Great Britain ${ }^{2}$. The main research question this paper addresses is "What is the relationship between the environmental and economic performance of firms in specific industrial sectors and what is the influence of corporate environmental strategies on this relationship?". Corporate environmental strategies (CES) are distinguished here in terms of end-of-pipe and integrated pollution prevention strategies (based on actual physical environmental performance of companies) both of which can also be linked to the Environmental Shareholder Value (ESV) concept of Schaltegger and Figge (1998).

\footnotetext{
${ }^{1}$ The sector classification is based on the NACE code i.e. NACE 21.1 (Pulp and Paper Manufacturing).

${ }^{2}$ Apart from the environmental relevance, the sector and the four countries have been chosen because a high number of companies produce environmental reports or site-level environmental statements under EMAS in the pulp and paper manufacturing sector in these countries. These are usually externally validated and guarantee sufficient availability of data. Additionally the paper sector produces fairly homogeneous products, which makes a comparison of physical environmental performance across firms in the sector possible.
} 
Environmental performance is characterized throughout this paper on the basis of quantitative indicators describing mass, energy and pollutant flows, and different specifications of environmental performance (linked to end-of-pipe or pollution prevention orientations, respectively) are related to the economic performance of firms in order to address the above research question and to identify a possible relationship between environmental and economic performance of firms. An important extension of prior work is that this research accounts for the possibility of a non-linear link between environmental and economic performance.

Following the argument made by Schaltegger and Synnestvedt (2002) an inversely U-shaped curve would represent the "best" possible case for the relationship between environmental and economic performance, since it allows for the existence of win-win situations with profitable environmental performance improvement activities. Alternatively, if environmental performance improvements can only increase costs and reduce profits for an individual firm, this would not be possible. Under such conditions, the optimal level of environmental performance for a firm would be the one prescribed by environmental regulations, i.e. compliance without over-compliance (represented by the dotted line in Figure 1 below).

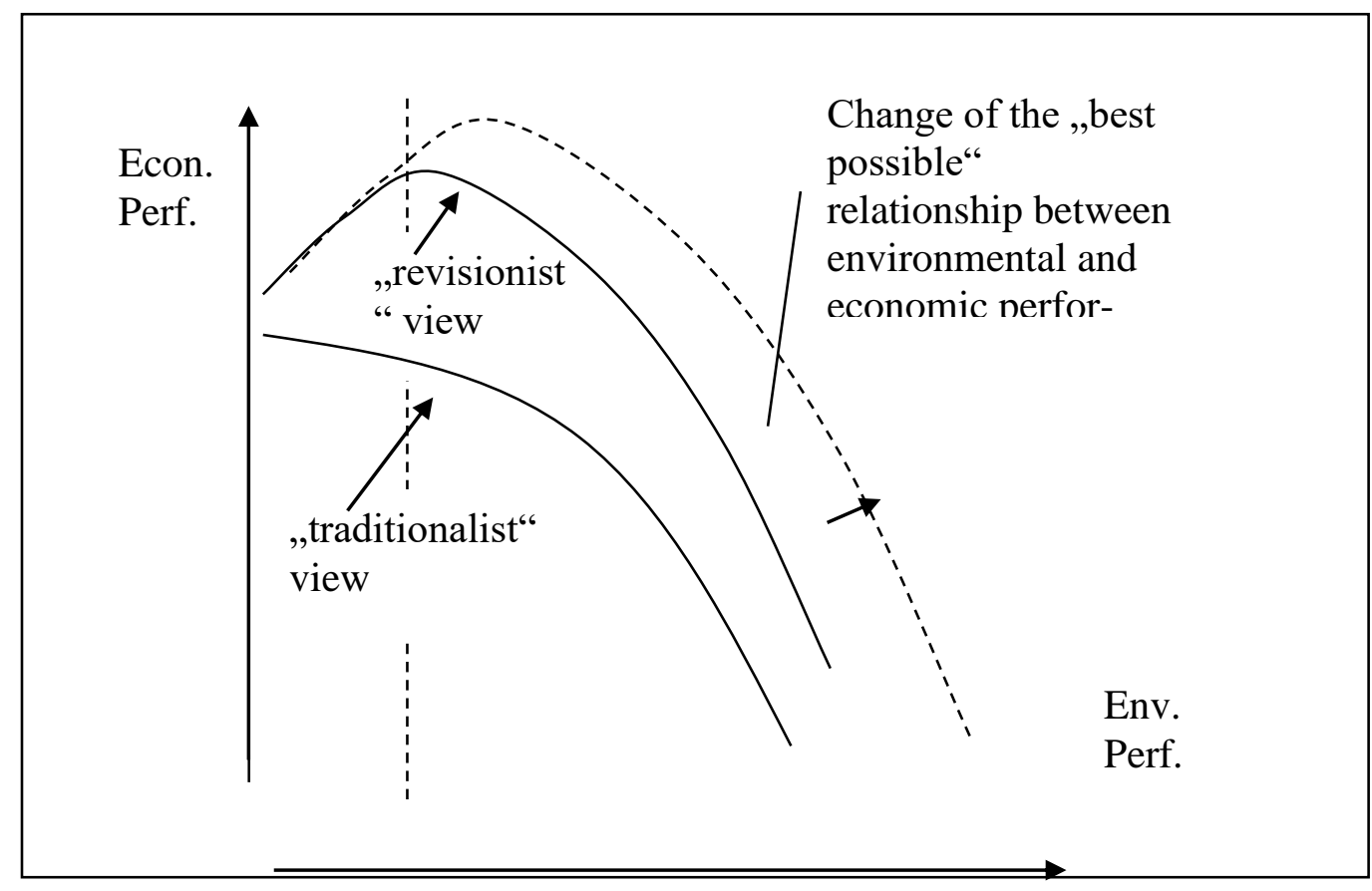

Figure 1: The link of environmental and economic performance (based on: Schaltegger 1988; Lankoski 2000; Wagner 2000; Schaltegger and Synnestvedt 2002; Wagner 2003) 
Figure 1 summarises these considerations in joining both relationships in one graphic representation. This also shows the possibility of the relationship evolving over time due to innovation, as suggested by Porter (1991). This means, that over time, for a defined level of environmental performance, the maximum realisable level of economic performance will increase (see Schaltegger and Synnestvedt 2002).

The hypothesis is now that the relationship between environmental and economic performance of firms is either inversely U-shaped or negative in its functional form (as concluded in Figure 1), and that strategy orientation with regard to sustainability and the environment (as a result of management's decision making) has some influence on the relationship as well, especially in terms of whether a firm puts its focus on end-of-pipe or pollution prevention strategies, respectively. The influence firms choosing a particular strategy is captured here through different specifications of the environmental performance measure used in the analysis. Based on this, the following hypotheses are proposed:

H1: Environmental performance has either a uniformly negative or an inversely $U$-shaped relationship with economic performance, after controlling for other influences on economic performance. It is also possible, that no significant relationship exists empirically, if the influence of environmental on economic performance is small compared to other factors.

H2: There is an influence of strategy orientation on the relationship between environmental and economic performance in that the choice of a strategic approach oriented towards pollution prevention results in a more positive relationship than that of an approach oriented towards end-of-pipe environmental protection.

Based on the statistical analysis of a multiple-country data set of firms in the European paper manufacturing industry, the hypothesis derived from the question stated above, that the relationship between environmental and economic performance is either inversely U-shaped or negative in its functional form, can be tested for different types of environmental performance measures reflecting different strategic orientations of a firm with regard to sustainability and the environment. This testing needs to take into account the influence of a number of important control variables. These variables are country membership, processes operated by firms, and firm size.

After briefly sketching out the basic research questions and hypotheses and the theoretical reasoning behind them, the next section will provide details on their measurement and on the empirical research methodology. Subsequently results of the econometric analysis are presented and discussed in detail. The final section draws conclusions and raises some policy issues. 


\section{Methodology}

This section introduces the methodological approach adopted for the empirical analysis, used to test the hypothesis stated in the Introduction and theoretically justified in the previous section. The research design of the empirical analysis is a statistical design using purposive survey methodology. It includes a number of instruments (various environmental performance indicators (EPIs) and financial ratios), on which data was collected for subjects from one industrial sector, namely the paper manufacturing sector). In the following, separate sections describe in detail (i) the subjects of this research, (ii) the instruments and measures used, (iii) the statistical analysis approaches and econometric specifications used in the empirical testing of the hypothesis formulated in the Introduction and (iv) the process data collection.

\section{Subjects}

The subjects of this research are firms from four European countries (Germany, Italy, the Netherlands and United Kingdom) in the pulp and paper manufacturing sector (as defined by the 2-digit NACE code). The firms chosen were either single-site firms (i.e. sites) or firms with very few sites. This was done because the control of common system boundaries is easier for single-site firms and firms with few sites than for multi-site firms with many sites. ${ }^{3}$ Although the paper manufacturing sector has different relative economic importance in the countries under observation, it contributes in all countries to essential human needs. To improve environmental performance in the paper manufacturing sector whilst not deteriorating economic performance is therefore essential to ultimately achieve sustainable development and sustainability in this sector and thus a necessary condition for achieving in the industrial society as a whole. Behmanesh et al. (1993) find the paper sector to be consistently ranked fourth amongst all manufacturing industries with regard to its environmental impacts, which supports the environmental relevance of the paper manufacturing sector and the relevance of environmental aspects for firms' economic performance in this sector.

Regarding the choice of countries included in the first empirical analysis, data availability needed to be sufficient in the paper sector as a whole, as well as in each individual country. These requirements could be met by choosing four European countries, namely Italy, the United Kingdom (UK), the Netherlands and Germany. In Germany as well as the in Netherlands, the extent of corporate environmental protection has achieved relatively high

\footnotetext{
${ }^{3}$ However, there are only very few multi-site firms in Europe and hence proceeding like this did not introduce a bias in the analysis.
} 
levels. However, in Germany command-and-control regulation is predominant, whereas in the Netherlands, a strong focus is on voluntary/negotiated instruments (e.g. negotiated industry agreements, so-called "covenants"). Generally, the economic relevance of the paper sector in all four countries chosen is very high, as can be seen from Table 1 below.

Table 1: Number of pulp and paper mills and rank of the chosen countries*

\begin{tabular}{l|l|l|l|l}
\hline Country & Paper mills & Pulp mills & Rank Paper* & Rank Pulp* \\
\hline United Kingdom & 97 & 4 & $5^{\text {th }}$ in EU & $10^{\text {th }}$ in EU \\
\hline The Netherlands & 25 & 2 & $10^{\text {th }}$ in EU & $12^{\text {th }}$ in EU \\
\hline Italy & 210 & 15 & $1^{\text {st }}$ in EU & $7^{\text {th }}$ in EU \\
\hline Germany & 198 & 20 & $2^{\text {nd }}$ in EU & $3^{\text {rd }}$ in EU \\
\hline
\end{tabular}

(Source: CEPI 1998; *Rank is based on the share (in \%) of the respective country in total EU physical production of paper and pulp, respectively. The higher the share, the better the rank.)

Table 1 shows that with Italy and Germany, the countries with the two largest national paper manufacturing sectors in the EU are included in the data set. With the UK and the Netherlands, two further countries are included, in which the paper industry has relatively lower, yet still significant importance, as confirmed by their respective ranks.

\section{Instruments and measures}

Quantitative measures of environmental and economic performance are particularly suited for an analysis of the relationship between environmental and economic performance for a number of reasons. Firstly, they can often be derived from publicly available information sources, such as financial reports or pollutant release and transfer registers (e.g. the Dutch Emissions Register for Industry (ER-I), the U.S. Toxic Release Inventory (TRI), and the UK Pollution Inventory).

Secondly, quantitative indicators measure the outcomes of firms' environmental management activities and are thus more suited for a description of environmental and economic performance than effort measures (such as the amount of environmental management activities). Thirdly, environmental performance indicators (i.e. normalised measures of environmental performance) and financial ratios (as well as market-based measures) have been used in several empirical studies to analyse the relationship between environmental and economic performance (e.g. Cohen et al. 1995; Hart and Ahuja 1996; Johnson 1996; Edwards 1998; Konar and Cohen 2001, Ziegler et al. 2002; Al-Tuwaijri et al. 2004). Therefore, in the empirical analysis, no own instruments are developed, but well-established EPIs whose 
reliability and validity has been extensively tested (for example recently in the MEPI research project, see Berkhout et al. 2001) are chosen. To proceed this way is often advocated over developing new instruments in the literature (Rudestam and Newton 1992).

The variables used to operationalise the concept environmental performance are $\mathrm{SO}_{2}$ emissions, $\mathrm{NO}_{\mathrm{x}}$ emissions, $\mathrm{COD}$ emissions, total energy input, and total water input, all per tonne of paper produced. Olsthoorn et al. (2001) support the use of these indicators in the paper sector. Also, only for these variables used to operationalise environmental performance, data was sufficiently available to allow for meaningful analysis and results (in terms of not reducing too much the representativeness and thus generalisability of the results). Regarding the use of value added instead of physical production output (i.e. tonnes of paper produced) as denominator to normalise absolute environmental performance, there are theoretical arguments justifying the use of either of the two. Physical production output was used nevertheless, since the price of paper on the world markets dropped significantly between 1995 and 1996. It was assumed that this would influence more strongly value added than physical production output. In order to avoid distortions because of this, the latter was used as denominator. This choice is further supported by the high correlation of value added and physical production output in the data set.

In order to use the above individual environmental performance indicators (all normalized to production output) in the regression analyses, two composite indices of these had to be calculated, using the method initially developed by Jaggi and Freedman (1992) in the adaptation used in Berkhout et al. (2001: 140) who also explain the precise method for index calculation. The indicators used to calculate scores for the first (outputs-oriented) index score were $\mathrm{SO}_{2}, \mathrm{NO}_{\mathrm{x}}$, and COD. For the second (inputs-oriented) index score, total energy input and total water input were used. The reason for using two indices was firstly, that differentiation between inputs and outputs orientation allows assessment of methodological effects on the results. Secondly, the data was used more efficiently this way, since more cases could be included in the analysis. Thirdly, the inputs-oriented index reflects more pollution prevention, whereas the outputs-oriented index reflects more end-of-pipe activities.

The reason for this last point is that pollution prevention activities have per definition a stronger effect in inputs to production than have end-of-pipe programmes. Therefore, an input-oriented index captures mainly the effect of integrated pollution prevention strategies on economic performance. The ESV concept (Schaltegger and Figge 1998) argues that their effect on the latter should be more positive than that of end-of-pipe activities. Since end-ofpipe as well as pollution prevention activities both decrease emissions, an (undesired) 
outputs-based index of environmental performance reflects both strategies. Since ESV argues that end-of-pipe activities have generally a negative effect on economic performance, the relationship of such an index with the latter should be more negative.

Economic performance can be approximated in the short term through accounting-based measures such as profitability. Therefore, in this paper, economic performance is measured in terms of operating profit financial ratios (esp. profitability/ efficiency ratios). Profitability ratios considered in the following are return on sales (ROS) and return on owners' capital employed (ROCE), and return on equity (ROE). These ratios have been used in studies in the U.S. and Europe (Cohen et al. 1995; Hart and Ahuja 1996; Edwards 1998) to assess the relationship between environmental and economic performance and are therefore considered particularly valuable, partly because they allow (at least to some degree) a comparison between the results studies for Europe and the United States. Since multi-colinearity between these measures is high, they can only be used separately.

Next to the variables to be used to measure the concepts of environmental and economic performance, a number of economic control variables were included in this research in the regressions with economic performance as dependent variable. These are the asset-turnover ratio, the gearing ratio/ debt-to-equity ratio, firm size and the square of firm size, and country dummy variables. The use of the square of firm size addresses potential non-linearities and this variable is often used in applied econometric work (e.g. Wagner 1998). Finally, a subsector classification was developed for the paper sector, on the basis of which sub-sector dummy variables were defined and included into the regression equations.

Use of the asset-turnover ratio has been suggested by Russo and Fouts (1997) and by Schaltegger and Figge (1998) to control for differences in capital intensity. Hart and Ahuja (1996) suggest inclusion of the debt-to-equity ratio to control for differences in capital structure. The debt-to-equity ratio is calculated in this research as the inverse of the solvency ratio, less than one (i.e. debt-to-equity ratio $=(1 /$ solvency ratio $)-1)$. The solvency ratio is defined as the ratio of shareholder funds to total assets.

Next to the variables described above to measure the concepts of environmental and economic performance respectively, and the sector dummy variables accounting for the sub-sectors firms are operating in, country dummy variables for the four countries in which data was collected for paper manufacturing firms, as well as a variable measuring the size of firms (in thousands of employees) were used as variables in the first empirical analysis of this research. Table 2 lists all variables used in empirical analysis of the research. The precise definitions of economic and control variables, as provided in Table 2, are according to Belzer (2000). 
Table 2: Summary of variable definitions for all variables used in the empirical analysis

\begin{tabular}{|c|c|c|c|}
\hline Concept & Variable & Description & Type $^{4}$ \\
\hline $\begin{array}{l}\text { Economic } \\
\text { perfor- } \\
\text { mance }\end{array}$ & ROE & $\begin{array}{l}\text { return on capital employed [\%], defined as: (pre-tax } \\
\text { profit + interest paid) / (shareholders' funds + non- } \\
\text { current liabilities)*100 } \\
\text { return on equity [\%], defined as: pre-tax profit (loss) / } \\
\text { shareholders' funds*100 } \\
\text { return on sales [\%], defined as: pre-tax profit (loss) / } \\
\text { operating revenue*100 }\end{array}$ & $\begin{array}{l}\text { conti- } \\
\text { nuous } \\
\text { (cont.) } \\
\text { cont. } \\
\text { cont. }\end{array}$ \\
\hline $\begin{array}{l}\text { Environ- } \\
\text { mental } \\
\text { perfor- } \\
\text { mance }\end{array}$ & $\begin{array}{l}\mathrm{COD} \\
\mathrm{SO}_{2} \\
\mathrm{NO}_{x} \\
\text { Energy input } \\
\text { Water input }\end{array}$ & $\begin{array}{l}\text { emission of chemical oxygen demand per output }[\mathrm{kt} / \mathrm{t}] \\
\text { emission of sulphur dioxide per unit of output }[\mathrm{kt} / \mathrm{t}] \\
\text { emission of nitrogenous oxides per unit of output[kt/t] } \\
\text { total energy input per unit of output [GWh/t] } \\
\text { total water input per unit of output [1000 litres/t] }\end{array}$ & $\begin{array}{l}\text { cont. } \\
\text { cont. } \\
\text { cont. } \\
\text { cont. } \\
\text { cont. }\end{array}$ \\
\hline $\begin{array}{l}\text { Control } \\
\text { variables in } \\
\text { regression }\end{array}$ & $\begin{array}{l}\text { debt-to-equity } \\
\text { ratio }\end{array}$ & $\begin{array}{l}\text { inverse of solvency ratio minus one [solvency ratio } \\
\text { measured in \%, defined as: shareholders' funds/ total } \\
\text { assets*100], proxying for gearing/financial leverage }\end{array}$ & cont. \\
\hline analyses & $\begin{array}{l}\text { asset turnover } \\
\text { ratio }\end{array}$ & $\begin{array}{l}\text { inverse of turnover-to-asset ratio [GBP/GBP], defined } \\
\text { as: total assets per operating revenue, proxying for } \\
\text { capital intensity }\end{array}$ & cont. \\
\hline Country & $\begin{array}{l}\text { United } \\
\text { Kingdom } \\
\text { Italy } \\
\text { Netherlands } \\
\text { Germany }\end{array}$ & $\begin{array}{l}\text { Firm located in the United Kingdom } \\
\text { Firm located in Italy } \\
\text { Firm located in the Netherlands } \\
\text { Firm located in Germany (reference group) }\end{array}$ & $\begin{array}{l}\text { dummy } \\
\text { (dum.) } \\
\text { dum. } \\
\text { dum. } \\
\text { dum. }\end{array}$ \\
\hline Sub-sector & $\begin{array}{l}\text { Industrial } \\
\text { Cultural } \\
\text { Mixed } \\
\text { Other }\end{array}$ & $\begin{array}{l}\text { Packaging corrugated and other boards } \\
\text { Newsprint, magazine-grade, graphics fine paper } \\
\text { (reference group) } \\
\text { Cultural and industrial paper production combined } \\
\text { Other paper production }\end{array}$ & $\begin{array}{l}\text { dum. } \\
\text { dum. } \\
\text { dum. } \\
\text { dum. }\end{array}$ \\
\hline Other & Firm size & Number of employees (thousands) & cont. \\
\hline
\end{tabular}

\footnotetext{
${ }^{4}$ In the table, cont. (abbreviating for continuous) and dum. (abbreviating for dummy) refer to continuous (interval/ratio scale) type and dummy type variables, respectively.
} 


\section{Econometric specifications}

The analysis of the empirical relationship of environmental and economic performance of firms involves an estimation procedure based on a panel data model, which the indicators used to measure environmental performance are considered to influence the economic performance variables which are treated as the endogenous variables. For the analysis, a pooled model based on Ordinary Least Squares (OLS) regression and ignoring the panel structure, a random effects panel data model and a fixed effects panel data model are used. The pooled model ignores the panel structure of the data and is estimated using OLS regression. It has the specification:

$$
y_{i t}=\alpha+\mathbf{x}_{i t} \beta+\mathbf{z}_{i} \gamma+\boldsymbol{u}_{i t}
$$

where $\mathrm{i}=1 . . \mathrm{N}$ units under observation; and $\mathrm{t}=1$.. T time periods for which data is collected. In this specification, $\mathrm{y}_{i t}$ denotes the observation on the dependent variable (economic performance) for a firm $\mathrm{i}$ in a period t. $\mathbf{x}_{i t}$ represents the set of time-variant independent variables (i.e. regressors), and $\mathbf{z}_{i}$ the time-invariant explanatory variables. ${ }^{5}$

However, ignoring the panel structure of the data can be problematic for two reasons (Johnston and DiNardo 1997). Firstly this is because even though the pooled model yields consistent estimates of the regression coefficients, standard errors will be under- and significance levels hence be overstated. Secondly, compared to Generalised Least Squares (GLS) regression, the use of OLS as estimation method does not result in efficient estimates of the regression coefficients.

To address these problems, two well-established models, random and fixed effects exist. The difference between the fixed effects and the random effects model is based on whether the time-invariant effects are correlated with the regressors (which is the case for the fixed effects) or (in case of the random effects model) not. For the random effects model for panel data, the specification is as in (1), however

with

$$
u_{i t}=\mu_{i}+\varepsilon_{i t}
$$

In (2), $\mathrm{u}_{i t}$ is composed of the disturbance $\mu_{i}$ reflecting left-out variables that are considered time-persistent (in the sense that for each firm i, these remain broadly the same over time) and the idiosyncratic error $\varepsilon_{i t .}{ }^{6}$ For the fixed effects model, other than the random effects model,

\footnotetext{
${ }^{5}$ The errors $\mathrm{u}_{\mathrm{it}}$ here are assumed to be identically and independently distributed i.e. the observations are assumed to be serially uncorrelated across individuals and time and the errors are assumed to be homoscedastic, and the assumptions of the classical linear model are met. Under these conditions OLS is an efficient estimation method. ${ }^{6}$ In the random effects model, the disturbance is a random variable, which is however constant for each observation on one specific firm. This means that observations of that one firm are considered to be more similar, than those on different firms (Johnston and DiNardo 1997; Kohler and Kreuter 2001). In the random effects model,
} 
the assumption is that the individual effect $\mu_{i}$ is correlated with the time-variant independent variables $\mathbf{x}_{i t}$. This means that although the basic specification given in (2) and (3) remains, the interpretation differs, in that the disturbance $\mu_{i}$ is a constant (and thus represented by a dummy variable) for each unit of analysis, i.e. here for each specific firm. The fact that the disturbance is a constant in the fixed effects model implies that all time-invariant variables will be dropped during the estimation. ${ }^{7}$ To decide, which of the two models (random or fixed effects) is more approriate, the $\mathrm{Wu}$-Hausman and the Breusch-Pagan tests are used. ${ }^{8}$

For testing the research question using the panel regression framework described above, incomplete panel data was used on a set of 37 paper firms in four EU countries (Germany, Italy, Netherlands and United Kingdom) over the period from 1995 to 1997. Table 3 provides an overview of the coverage of the paper sector as a whole in each country for the years 1996 and 1997. For 1995, data on the total production capacity, which was necessary for the assessment of coverage, was not available.

Table 3: Overall coverage of the paper sector in the countries (based on annual production)

\begin{tabular}{c|c|c|c|c|c|c|c|c}
\hline & $\begin{array}{c}\text { Coverage by } \\
\text { sample 1995 }\end{array}$ & $\begin{array}{c}\text { Total } \\
\mathbf{1 9 9 5}\end{array}$ & $\begin{array}{c}\text { Covered by } \\
\text { sample 1996 }\end{array}$ & Total 1996 & $\begin{array}{c}\text { Coverage } \\
\mathbf{1 9 9 6}\end{array}$ & $\begin{array}{c}\text { Covered by } \\
\text { sample 1997 }\end{array}$ & Total 1997 & $\begin{array}{c}\text { Coverage } \\
\mathbf{1 9 9 7}\end{array}$ \\
\hline Germany & 3775.290 & $\mathrm{~N} / \mathrm{a}$ & 3589.170 & 15890.000 & 0.226 & 3984.900 & 16893.000 & 0.236 \\
\hline Italy & 561.471 & $\mathrm{~N} / \mathrm{a}$ & 579.199 & 7850.000 & 0.074 & 801.695 & 8415.000 & 0.095 \\
\hline Netherlands & 1208.100 & $\mathrm{~N} / \mathrm{a}$ & 1211.600 & 3266.000 & 0.371 & 1275.000 & 3316.000 & 0.384 \\
\hline United Kingdom & 1445.199 & $\mathrm{~N} / \mathrm{a}$ & 1424.478 & 6812.000 & 0.209 & 1586.923 & 6798.000 & 0.233 \\
\hline All Countries & 6990.060 & $\mathrm{~N} / \mathrm{a}$ & 6804.447 & 33818.000 & 0.201 & 7648.518 & 35422.000 & 0.216 \\
\hline Countries overall & & $\mathrm{N} / \mathrm{a}$ & 33818.000 & 79115.000 & 0.427 & 35422.000 & 87408.000 & 0.405 \\
\hline
\end{tabular}

Sources: Own calculations for individual countries, CEPI (1998) for country totals; All values in kilo tonnes [kt]; Country totals refer to production capacity, not actual annual production.

the individual effect $\mu_{\mathrm{i}}$ is assumed to be uncorrelated with the time-variant independent variables $\mathrm{x}_{\mathrm{it}}$. The estimation method for the random effects model is GLS, which is efficient (Johnston and DiNardo 1997: 391). ${ }^{7}$ The reason for this is, that technically all time-invariant variables (represented by dummy variables) are fully multi-collinear with the (constant) disturbance (Kohler and Kreuter 2001; Johnston and DiNardo 1997: 397). Intuitively, this means that a change in the dependent variable for a specific unit of analysis for which observations exist cannot be attributed to a time-invariant variable, i.e. it cannot be said, which of the timeinvariant variables has caused the change observed in the dependent variable (Kohler and Kreuter 2001).

${ }^{8}$ If the $\mathrm{Wu}$-Hausman test is significant, then the null hypothesis that there is no significant difference between the estimation results for both models is rejected. Assuming that the model is correctly specified, this implies that the fixed effects model is more appropriate, i.e. it results in consistent and efficient estimates, whilst the estimates in the random effects model are inconsistent.

However, if the null hypothesis is not rejected, implying that the random effects model is valid, the fixed effects model still leads to consistent (but in this case inefficient) estimates (Johnston and DiNardo 1997: 402-403). To also test for the existence of random effects in cases, where the Wu-Hausman test turns out to be insignificant, the Breusch-Pagan test is additionally reported. If the test statistic of the Breusch-Pagan test is significant, the existence of random effects is confirmed. If it is insignificant, then in cases where also the Wu-Hausman test is insignificant, the pooled model based on OLS gives consistent and efficient estimates (StataCorp 1997). 
As can be seen from Table 3, percentage coverage changes little in each country from 1996 to 1997 due to the already mentioned even distribution of firms across countries and periods. Coverage is best in the Netherlands (approx. 37-38\%) and worst in Italy (approx.7-9\%). However this is also due to the fact that Italy has much larger total production capacity than the Netherlands. Also, it is necessary to take into consideration that total figures for each country are based on production capacity, not actual production. Thus, the figures are a conservative estimate of coverage. Given, that production is always smaller or equal to capacity, coverage may well be better than suggested by coverage figures.

\section{Results}

This section reports the results found when empirically evaluating the relationship between environmental and economic performance in the European paper industry based on the statistical procedures introduced above (random effects (RE) and fixed effects (FE) panel regressions and OLS regressions). The research hypotheses stated in the Introduction section of the paper were tested for two specifications of the environmental performance index (inputs- and outputs-based) during the empirical analysis. Results based on the panel regression framework described in the previous section are reported in the following.

\section{Results for the outputs-oriented environmental performance index}

This section reports results for the outputs-oriented environmental performance. In addition to the variables provided in Table 2, the squares of firm size and the respective environmental performance index were added in the regression in order to account for non-linearities in the relationship, especially for environmental performance, as argued in the Introduction of the paper. The results for the pooled data and the RE and FE models for different economic performance indicators are reported separately in Tables 4 to 6 for the three measures of economic performance used: return on capital employed (ROCE), return on sales (ROS) and return on equity (ROE). Also, the results of the Breusch-Pagan and Wu-Hausman tests are reported. As can be seen for ROCE, as dependent variable used to measure economic performance, the model with fixed effects is the best specification, since the Wu-Hausman test is significant. The FE model is also overall significant, and the hypothesis, that no fixed effects exist for any firm (i.e. that all $u_{i}$ are equal to zero) is also rejected. In the model, the linear term of the environmental index is significant (at the 1\% level) and has positive effect on ROCE. In addition to that, the squared term of the environmental index with a significance of $10.4 \%$ is 
almost significant (at the 10\% level) and has a negative effect on ROCE, and the effects are economically relevant. However, the short time-horizon of the analysis cannot fully rule out that some longer-term positive effects are not accounted for and that hence the negative relationship is somewhat less severe than found here. ${ }^{9}$ Firm size and its square, leverage, as well as the asset turnover ratio have no significant effect on ROCE. The level of environmental performance, which maximises ROCE in the FE model is equal to an index value of 0.12 .

Table 4: Estimation results for ROCE as dependent variable (outputs-based index)

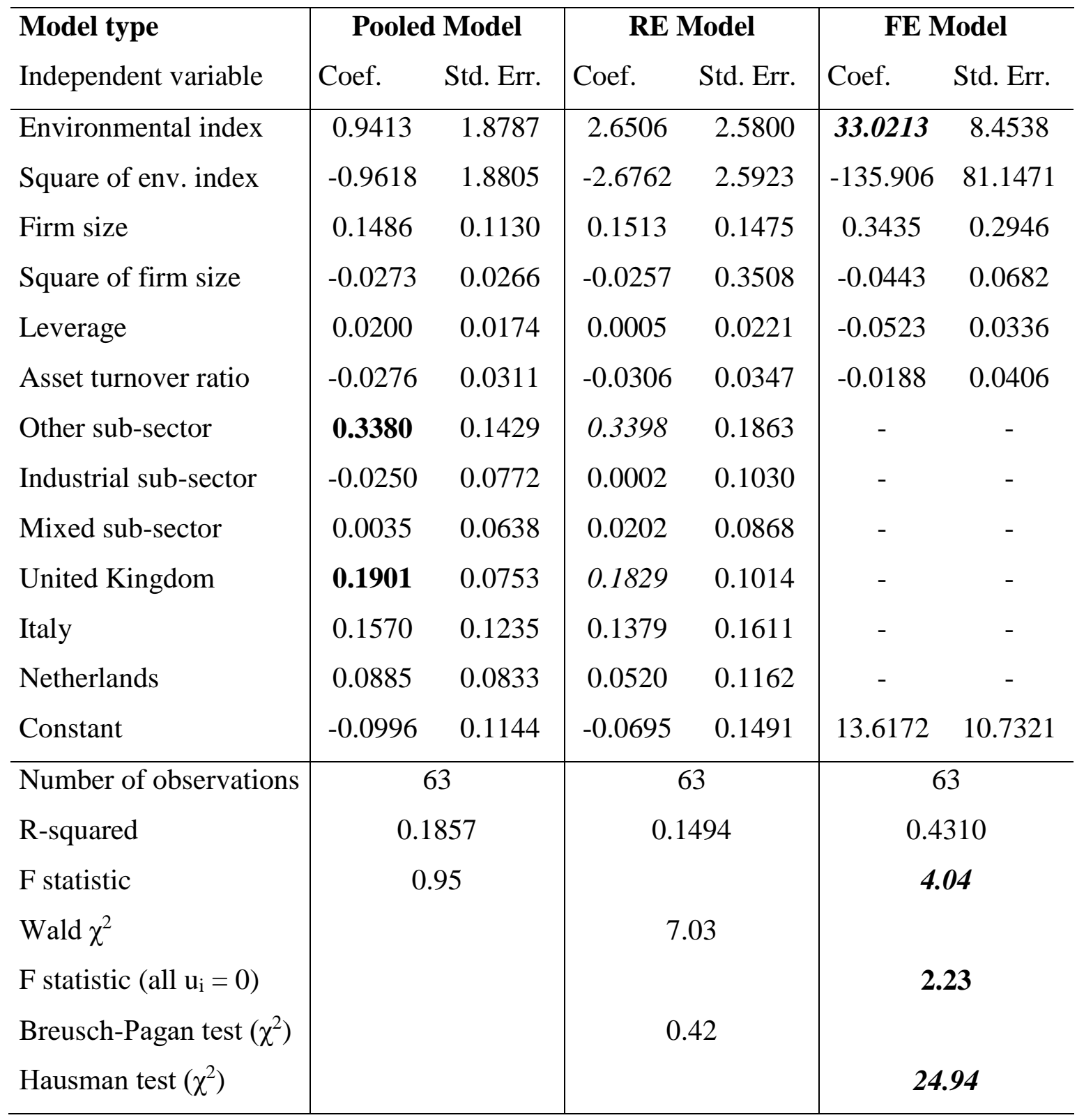

Bold and italic figures refer to significance at the 5\% and $10 \%$ levels, respectively. Figures that are bold and italicised at the same time refer to significance at the $1 \%$ level.

\footnotetext{
${ }^{9} \mathrm{I}$ am grateful to one of the anonymous reviewers for having pointed this out. For the results, this limitation is uncritical, since the paper's argument mainly rests on comparing results for inputs- and outputs-oriented indices.
} 
Concerning ROS as measure of firms' economic performance, it was found that the fixed effects specification is most appropriate (as signified by the significant $\mathrm{Wu}-H a u s m a n$ test and rejection of the hypothesis that all individual effects $u_{i}$ are simultaneously equal to zero).

Table 5: Estimation results for ROS as dependent variable (outputs-based index)

\begin{tabular}{|c|c|c|c|c|c|c|}
\hline \multirow{2}{*}{$\begin{array}{l}\text { Model type } \\
\text { Independent variable }\end{array}$} & \multicolumn{2}{|c|}{ Pooled Model } & \multicolumn{2}{|c|}{ RE Model } & \multicolumn{2}{|c|}{ FE Model } \\
\hline & Coef. & Std. Err. & Coef. & Std. Err. & Coef. & Std. Err. \\
\hline Environmental index & -0.0674 & 0.7138 & 0.1024 & 1.0904 & 2.7342 & 2.8037 \\
\hline Square of env. index & 0.0563 & 0.7159 & -0.1129 & 1.1000 & -71.6610 & 27.0024 \\
\hline Firm size & 0.0726 & 0.0422 & 0.0609 & 0.0575 & 0.0781 & 0.0979 \\
\hline Square of firm size & -0.0117 & 0.0101 & -0.0085 & 0.0140 & -0.0123 & 0.0227 \\
\hline Leverage & -0.0140 & 0.0062 & -0.0221 & 0.0073 & -0.0272 & 0.0093 \\
\hline Asset turnover ratio & 0.0341 & 0.0116 & 0.0151 & 0.0116 & 0.0149 & 0.0134 \\
\hline Other sub-sector & 0.0563 & 0.0350 & 0.0408 & 0.0549 & - & - \\
\hline Industrial sub-sector & -0.0139 & 0.0275 & -0.0087 & 0.0395 & - & - \\
\hline Mixed sub-sector & -0.0341 & 0.0249 & -0.0274 & 0.0380 & - & - \\
\hline United Kingdom & 0.0599 & 0.0281 & 0.0699 & 0.0421 & - & - \\
\hline Italy & 0.0483 & 0.0476 & 0.0455 & 0.0669 & - & - \\
\hline Netherlands & 0.0562 & 0.0309 & 0.0517 & 0.0478 & - & - \\
\hline Constant & -0.0285 & 0.0419 & 0.0165 & 0.0575 & 8.7277 & 3.3084 \\
\hline Number of observations & \multicolumn{2}{|c|}{68} & \multicolumn{2}{|c|}{68} & \multicolumn{2}{|c|}{68} \\
\hline R-squared & \multicolumn{2}{|c|}{0.4399} & \multicolumn{2}{|c|}{0.3803} & \multicolumn{2}{|c|}{0.3114} \\
\hline F statistic & \multicolumn{2}{|c|}{3.60} & & & \multicolumn{2}{|c|}{2.64} \\
\hline Wald $\chi^{2}$ & & & \multicolumn{2}{|c|}{20.85} & \multirow{2}{*}{\multicolumn{2}{|c|}{3.66}} \\
\hline F statistic $\left(\right.$ all $\left.u_{i}=0\right)$ & & & \multirow{3}{*}{\multicolumn{2}{|c|}{5.89}} & & \\
\hline Breusch-Pagan test $\left(\chi^{2}\right)$ & & & & & \multirow{2}{*}{\multicolumn{2}{|c|}{15.49}} \\
\hline Hausman test $\left(\chi^{2}\right)$ & & & & & & \\
\hline
\end{tabular}

Bold and italic figures refer to significance at the 5\% and $10 \%$ levels, respectively. Figures that are bold and italicised at the same time refer to significance at the $1 \%$ level.

Results indicate that the linear term of the environmental performance index has a positive but insignificant effect on ROS whilst the squared term of the index has a significant and negative effect, which is also relevant in economic terms. As for ROCE, not all longer-term effects may be captured in the analysis, since initial capital expenditure reduces profits in the short- 
term, thus potentially explaining that leverage has a significant negative effect on ROS (1\% level). The level of environmental performance, which maximises ROS in the fixed effects model corresponds to an index value of 0.0188 . Since the index takes only values between zero and one, this corresponds to a very low level of environmental performance, which is consistent with the observation that only a significant and increasingly negative effect of environmental on economic performance exists for ROS. Firm size and its square have no significant effect on ROS as dependent variable As well, the asset turnover ratio was found to be insignificant in the fixed effects model.

Table 6: Estimation results for ROE as dependent variable (outputs-based index)

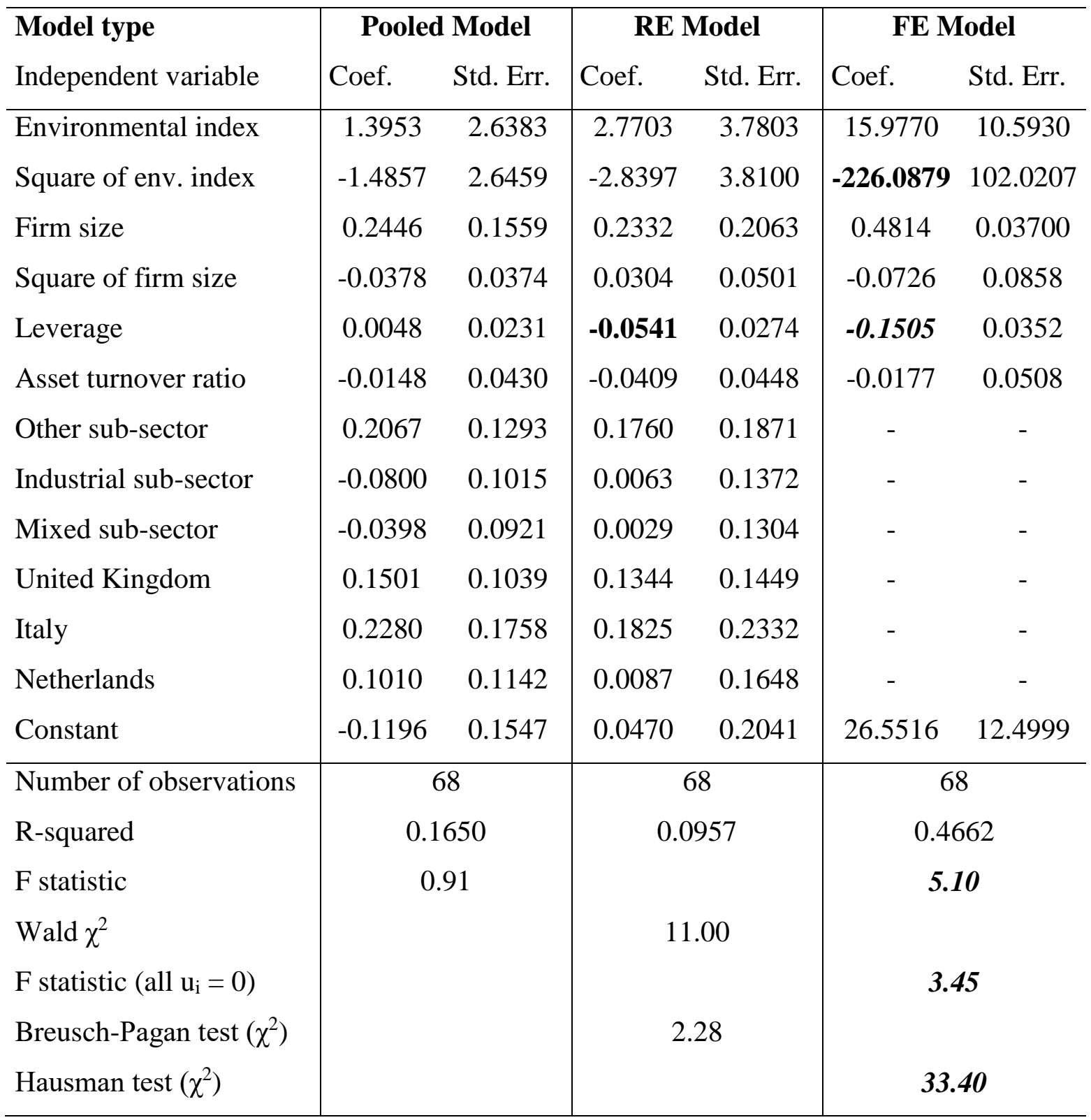

Bold and italic figures refer to significance at the 5\% and $10 \%$ levels, respectively. Figures that are bold and italicised at the same time refer to significance at the $1 \%$ level. 
For the estimations with ROE as dependent variable, similar findings were made as for ROS. Here again, fixed effects were found to be the most appropriate model. As for ROS, the linear term of the index has a positive, yet insignificant, effect on ROE. Opposed to this, the squared term has a significant negative effect on ROE, with the ROE-maximising level of environmental performance corresponding to an index value of 0.0353 . This effect is also relevant in economic terms, since a $10 \%$ increase in environmental performance reduces ROE by $22.6 \%$, all else being equal. Compared to this the significant negative effect of leverage is relatively small in terms of economic magnitude. As for ROS, leverage was found to have a significant negative effect on ROE in the FE model.

\section{Results for the inputs-oriented environmental performance index}

This section reports results for the input-based environmental performance index, again using the panel regression framework described earlier. As for the outputs-based index, in addition to the variables provided in Table 2, the squares of firm size and the respective environmental performance index were added in the regression in order to account for non-linearities in the relationship. The results for the pooled, the RE and the FE models for are reported in Tables 7 to 9, respectively and also the results of the Breusch-Pagan Lagrangian Multiplier and Hausman specification tests are provided.

As can be seen for ROCE as dependent variable used to measure economic performance, the model with RE is the best specification, since the Hausman test is insignificant (i.e. the fixed effects model is not better than the random effects model in that the estimated coefficients are not significantly different between the two models). Even though the Breusch-Pagan test is insignificant, i.e. it does not reject the null hypothesis that the variance of the $u_{i}$ equals zero for all $i$, the random effects model is still preferred over the pooled model, since the former is overall significant, but the latter not. In the model, the linear term of the environmental index, as well as its squared term are insignificant. Also, firm size and its square, leverage, as well as most dummy variables have no significant effect on ROCE. Only the asset turnover ratio has a significant negative (at the $10 \%$ level) and the dummy variable for the UK has a significant positive effect on ROCE (at the 5\% level) in the RE model as well as in the OLS model. However, the OLS model is overall insignificant. The effect of the asset turnover ratio is relatively small in economic terms. A unit increase in the asset turnover ratio would only decrease ROCE by $0.05 \%$, all else being equal (since ROCE is measured in percent). The effect of a firm being located in the UK increases ROCE by $0.23 \%$, relative to the case of a firm being located in Germany, all else being equal. 
Table 7: Estimation results for ROCE as dependent variable (input-based index)

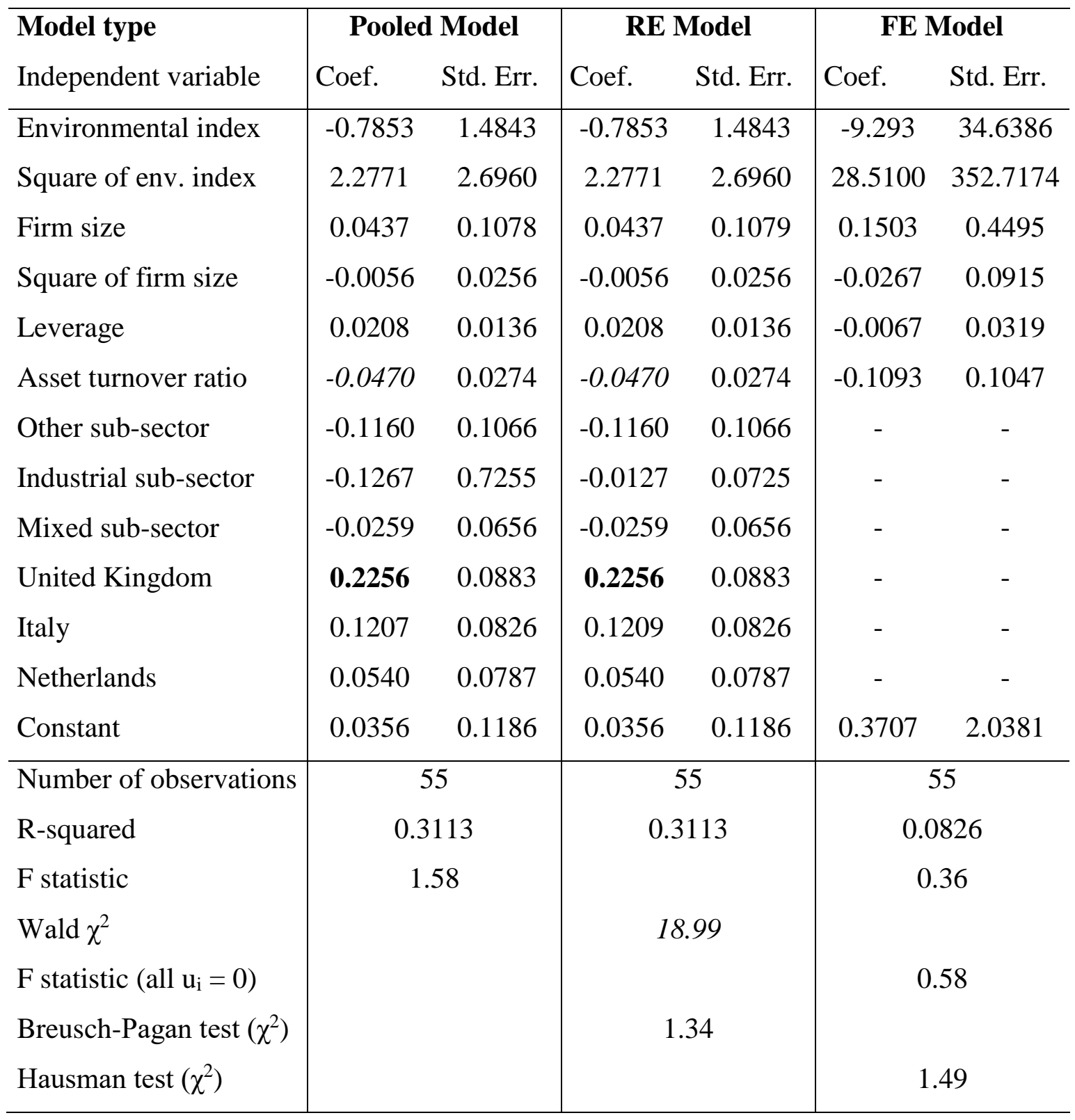

Bold and italic figures refer to significance at the 5\% and $10 \%$ levels, respectively. Figures that are bold and italicised at the same time refer to significance at the $1 \%$ level.

Concerning ROS, results indicate that the pooled model is most appropriate, since the Breusch-Pagan test is insignificant and since only the pooled model is overall significant. In the pooled model, the linear and the squared term for the environmental performance index are insignificant, as are the linear and the squared term of firm size, i.e. firm size has no significant effect on economic performance measured in terms of ROS. Both, leverage, as well as the asset turnover ratio have a significant negative effect on ROS at the $10 \%$ and $1 \%$ levels, respectively, in the pooled data model. 
Concerning sub-sector dummy variables (with the "Cultural" sub-sector being used as the reference group), the dummy for the "Mixed" sub-sector has a significant negative effect (10\% level) in the pooled model on ROS. Regarding country dummy variables (with Germany being used as the reference group), United Kingdom, Italy and the Netherlands were found to be significant and positive in the pooled regressions for ROS at the $1 \%, 10 \%$ and $5 \%$ levels, respectively. However, for Italy and the Netherlands, the significant effects in the pooled model become insignificant in the random effects model. Only the positive effect of the United Kingdom (compared to Germany) dummy remains significant at the 5\% level.

Table 8: Estimation results for ROS as dependent variable (input-based index)

\begin{tabular}{|c|c|c|c|c|c|c|}
\hline \multirow{2}{*}{$\begin{array}{l}\text { Model type } \\
\text { Independent variable }\end{array}$} & \multicolumn{2}{|c|}{ Pooled Model } & \multicolumn{2}{|c|}{ RE Model } & \multicolumn{2}{|c|}{ FE Model } \\
\hline & Coef. & Std. Err. & Coef. & Std. Err. & Coef. & Std. Err. \\
\hline Environmental index & 0.3741 & 0.5207 & 0.4179 & 0.6436 & -9.8877 & 9.3986 \\
\hline Square of env. index & -0.7689 & 0.9664 & -0.8542 & 1.1789 & 75.8150 & 98.3765 \\
\hline Firm size & 0.0616 & 0.0396 & 0.0498 & 0.0531 & -0.0155 & 0.1271 \\
\hline Square of firm size & -0.0084 & 0.0094 & -0.0055 & 0.0128 & -0.0011 & 0.0258 \\
\hline Leverage & -0.0097 & 0.0049 & -0.0105 & 0.0057 & -0.0101 & 0.0090 \\
\hline Asset turnover ratio & -0.0279 & 0.0099 & -0.0137 & 0.0115 & -0.0366 & 0.0278 \\
\hline Other sub-sector & -0.0044 & 0.0280 & -0.0031 & 0.0433 & - & - \\
\hline Industrial sub-sector & 0.0016 & 0.0250 & -0.0205 & 0.0350 & - & - \\
\hline Mixed sub-sector & -0.0412 & 0.0237 & -0.0318 & 0.0339 & - & - \\
\hline United Kingdom & 0.0873 & 0.0304 & 0.0898 & 0.0444 & - & - \\
\hline Italy & 0.0601 & 0.0302 & 0.0586 & 0.0425 & - & - \\
\hline Netherlands & 0.0731 & 0.0281 & 0.0530 & 0.0402 & - & - \\
\hline Constant & -0.0498 & 0.0431 & -0.0299 & 0.0575 & -0.1023 & .5305 \\
\hline Number of observations & \multicolumn{2}{|c|}{59} & \multicolumn{2}{|c|}{59} & \multicolumn{2}{|c|}{59} \\
\hline R-squared & \multicolumn{2}{|c|}{0.4578} & \multicolumn{2}{|c|}{0.4181} & \multicolumn{2}{|c|}{0.0951} \\
\hline F statistic & \multicolumn{2}{|c|}{3.24} & & & \multicolumn{2}{|c|}{0.46} \\
\hline Wald $\chi^{2}$ & & & \multicolumn{2}{|c|}{15.02} & \multirow{2}{*}{\multicolumn{2}{|c|}{1.69}} \\
\hline F statistic $\left(\right.$ all $\left.u_{i}=0\right)$ & & & \multirow{3}{*}{\multicolumn{2}{|c|}{0.17}} & & \\
\hline Breusch-Pagan test $\left(\chi^{2}\right)$ & & & & & \multirow{2}{*}{\multicolumn{2}{|c|}{6.92}} \\
\hline Hausman test $\left(\chi^{2}\right)$ & & & & & & \\
\hline
\end{tabular}

Bold and italic figures refer to significance at the 5\% and $10 \%$ levels, respectively. Figures that are bold and italicised at the same time refer to significance at the $1 \%$ level. 
In terms of economic relevance, for ROS as dependent variable, leverage has a relatively small influence only, since a unit increase in leverage would only result in a $0.01 \%$ decrease of ROS, all else being equal, whereas a unit increase of the asset turnover ratio would result in an almost $0.03 \%$ decrease of ROS. Sector membership in the "Mixed" sub-sector reduces ROS by $0.04 \%$, compared to membership in the "Cultural" sub-sector. Compared to these effects, country membership is more relevant in economic terms, since location in Italy, the Netherlands or the UK increases ROS by between $0.06 \%$ to $0.09 \%$, relative to Germany.

Table 9: Estimation results for ROE as dependent variable (input-based index)

\begin{tabular}{|c|c|c|c|c|c|c|}
\hline \multirow{2}{*}{$\begin{array}{l}\text { Model type } \\
\text { Independent variable }\end{array}$} & \multicolumn{2}{|c|}{ Pooled Model } & \multicolumn{2}{|c|}{ RE Model } & \multicolumn{2}{|c|}{ FE Model } \\
\hline & Coef. & Std. Err. & Coef. & Std. Err. & Coef. & Std. Err. \\
\hline Environmental index & -0.9554 & 1.6794 & -0.7280 & 1.8663 & -34.8707 & 32.6102 \\
\hline Square of env. index & 1.4652 & 3.1169 & 0.9647 & 3.4336 & 241.249 & 341.3374 \\
\hline Firm size & 0.0631 & 0.1277 & 0.0659 & 0.1525 & -0.0332 & 0.4408 \\
\hline Square of firm size & 0.0037 & 0.0303 & 0.0036 & 0.0366 & -0.0136 & 0.0897 \\
\hline Leverage & 0.0013 & 0.0157 & -0.0084 & 0.0174 & -0.0341 & 0.0312 \\
\hline Asset turnover ratio & -0.0333 & 0.0321 & -0.0500 & 0.0355 & -0.2089 & 0.0965 \\
\hline Other sub-sector & -0.0298 & 0.0902 & -0.0304 & 0.1169 & - & - \\
\hline Industrial sub-sector & -0.0110 & 0.0808 & 0.0169 & 0.0979 & - & - \\
\hline Mixed sub-sector & -0.1141 & 0.0766 & -0.1070 & 0.0941 & - & - \\
\hline United Kingdom & 0.2064 & 0.0980 & 0.2073 & 0.1222 & - & - \\
\hline Italy & 0.1562 & 0.0974 & 0.1756 & 0.1185 & - & - \\
\hline Netherlands & 0.0782 & 0.0908 & 0.0347 & 0.1116 & - & - \\
\hline Constant & 0.0581 & 0.1391 & 0.0904 & 0.1637 & -0.0697 & 1.8406 \\
\hline Number of observations & \multicolumn{2}{|c|}{59} & \multicolumn{2}{|c|}{59} & \multicolumn{2}{|c|}{59} \\
\hline R-squared & \multicolumn{2}{|c|}{0.2564} & \multicolumn{2}{|c|}{0.2424} & \multicolumn{2}{|c|}{0.2108} \\
\hline F statistic & \multicolumn{2}{|c|}{1.32} & & & \multicolumn{2}{|c|}{1.16} \\
\hline Wald $\chi^{2}$ & & & \multicolumn{2}{|c|}{11.85} & \multirow{2}{*}{\multicolumn{2}{|c|}{1.32}} \\
\hline F statistic $\left(\right.$ all $\left.u_{i}=0\right)$ & & & \multirow{3}{*}{\multicolumn{2}{|c|}{0.04}} & & \\
\hline Breusch-Pagan test $\left(\chi^{2}\right)$ & & & & & \multirow{2}{*}{\multicolumn{2}{|c|}{5.09}} \\
\hline Hausman test $\left(\chi^{2}\right)$ & & & & & & \\
\hline
\end{tabular}

Bold and italic figures refer to significance at the 5\% and $10 \%$ levels, respectively. Figures that are bold and italicised at the same time refer to significance at the $1 \%$ level. 
Concerning the model with ROE as dependent variable, none of the models estimated is overall significant, nor are the Hausman and Breusch-Pagan tests. Since the pooled and the random effects models do not differ qualitatively, results are reported for these two, given that they are the most suitable ones in the absence of fixed effects (i.e. the hypothesis that all $u_{i}$ are simultaneously equal to zero could not be rejected). In both, the pooled and the random effects models, both, the linear and squared terms of the environmental performance index and of firm size were found to be insignificant, as were firm size and its square. In fact, the only significant independent variable was the dummy for firms located in the United Kingdom. This dummy was positive and had a significant effect at the 5\% level in the pooled and at the $10 \%$ level in the random effects (RE) model. In terms of economic relevance, location of a firm in the UK increased ROE by $0.21 \%$, relative to a firm being located in Germany. Whilst this is a relative moderate increase in absolute terms, it is still approximately two to three times higher than the effect observed in the case of ROS. Therefore, the effect is also somewhat relevant in economic terms, at least in a comparative perspective with the other measures of economic performance. All other independent variables in the pooled and random effects models were found to be insignificant.

To end the Results section, the salient results of the empirical analysis are summarized, in particular with regard to their meaning for the research hypotheses $\mathrm{H} 1$ and H2. Following this, some more practical comments on the managerial implications of the results are made which bridge to the more general evaluation in the Conclusions section.

One key salient finding of the analysis for all measures of economic performance is that for the outputs-based index of environmental performance, a largely negative relationship, as predicted in hypothesis H1, is found, whereas for an inputs-based index, the relationship is generally insignificant. With the indices taking values between zero and one, the economic performance-maximising values of environmental performance for the outputs-based index correspond to a relatively low level of environmental performance for all three measures of economic performance, ROCE, ROS and ROE. The managerial implication of this finding is, that focusing in improvements of environmental performance in terms of reducing (undesired) outputs (i.e. emissions) from production is unlikely to bring about a positive influence on economic performance beyond relatively low levels of environmental performance. Since an outputs-based index of environmental performance captures the joint effect of end-of-pipe and pollution prevention strategies, this implies that pursuing solely an end-of-pipe strategy is unlikely to result into a positive relationship between environmental and economic performance. This interpretation (which confirms hypothesis H2) is supported in two ways. 
Firstly, the corresponding result for the different measures of economic performance and an inputs-based environmental performance index (which solely captures the effect of pollution prevention strategies) is that there is no significant negative effect of environmental on economic performance. This means that for higher levels of environmental performance, the relationship is more positive than for an outputs-based index, all else being equal.

Secondly, the ESV concept (Schaltegger and Figge 1998) provides theoretical justification for this interpretation. In short, ESV stipulates, that for a defined level of environmental performance, economic performance can be improved more the stronger the environmental management activities of a company are linked to the key value drivers of shareholder value (Rappaport 1986). The ESV concept from this derives, that efficiency improvements brought about by means of an integrated pollution prevention strategy usually only require limited additional investments (compared with add-on equipment for an end-of-pipe strategy) and may as well result in reduced operating costs and therefore higher profit margins. All of these aspects have a favorable effect on the value drivers of shareholder value and should thus lead to a more potive relationship of environmental and economic performance. This theoretically explains why a pollution prevention orientation empirically results in a more positive relationship of environmental and economic performance. Table 10 briefly summarises all salient results.

Table 10: Summary of results

\begin{tabular}{|c|c|}
\hline Research aspect & Finding \\
\hline Hypothesis H1 & $\begin{array}{l}\text { Partly confirmed: no significant relationship for inputs-based index; } \\
\text { largely negative relationship for outputs-based index (except ROS: } \\
\text { inversely U-shaped relationship) }\end{array}$ \\
\hline Hypothesis H2 & $\begin{array}{l}\text { Confirmed in a comparative perspective: no significant effect of } \\
\text { environmental on economic performance for inputs-based index; } \\
\text { largely negative effect for outputs-based index }\end{array}$ \\
\hline Firm size effects & No significant firm size effects on economic performance \\
\hline Economic factors & Negative effect of leverage (stronger for outputs-based index) \\
\hline Sub-sector effects & "Mixed" sub-sector has negative effect on economic performance \\
\hline Country influence & Significant positive effect of UK location on economic performance \\
\hline
\end{tabular}




\section{Conclusions}

Based on the results presented in the previous section, the significant coefficients in the panel regressions models are now discussed with regard to the implications they have for the relationship between environmental and economic performance. Overall, the results confirm the inversely U-shaped relationship between environmental and economic performance formulated at the beginning of the paper for the outputs-oriented environmental performance index in the fixed effects models. The positive part of the relationship was however found to be relatively weak. For the input-oriented environmental performance index, where the pooled models are most appropriate, no significant relationship could be detected.

The results found for financial leverage in terms of the debt-to-equity ratio in the most appropriate models (fixed effects for the outputs-oriented index and the pooled model for the inputoriented index) do not show a very clear pattern. Generally, the non-significance of leverage in the case of ROCE for both indices is in-line with theoretical reasoning, since theoretically ROCE in the way it is calculated should not be affected by capital structure. Also, the significant negative of leverage on ROS and ROE on economic performance in the model with an outputs-based index of environmental performance is consistent with theory. This increases the confidence, which can be put into the basic model specification in terms of the dependent and independent variables. The fact, that leverage is less significant for the model with an inputs-oriented environmental performance index should also be noted. Since firms in both regressions are identical, it cannot be explained with different levels of debt finance. Given that the inputs-based index is linked more strongly to pollution prevention, one explanation could be that initial capital expenditure (which reduces short-term profits) is smaller here, than for an end-of-pipe approach more strongly reflected by the outputs-based index and that therefore leverage has a less significant negative effect in the set of regressions with an inputs-based index of environmental performance. Beyond this, the gearing/debt-toequity ratio, as well as the asset turnover ratio (for which similar arguments hold) should partly be understood as necessary control variables in regression models with economic performance as dependent variable, without which equations may be misspecified and, as a result, estimates may be biased.

Firm size has no significant influence on the three economic performance variables in the relevant models (regardless of the type of environmental index) of the empirical analysis. This provides very strong evidence that as far as the effect of firm size on economic performance is concerned, no significant effect exists at the level of one individual industry sector. 
Concerning sub-sector dummies in the estimations with the environmental index based on energy and water inputs, the "Mixed" sub-sector dummy variable has a significant negative effect at the $10 \%$ level on ROS. For all other estimations with the index based on energy and water inputs, the coefficients for the sub-sector dummy variables were found to be insignificant. Also, sub-sector dummies were insignificant for all equations with the outputs-oriented environmental performance index based on $\mathrm{COD}, \mathrm{NO}_{\mathrm{x}}$ and $\mathrm{SO}_{2}$, except for a significant negative effect (at the 5\% level) of the dummy variable for the "Other" sub-sector on ROCE in the pooled model. However, here the pooled model was inferior to the fixed effects model. Therefore there is remarkable homogeneity in the results of the first empirical analysis in that of the sub-sector dummies included in the models (when focusing on the most appropriate specification for each estimation) only the "Mixed" sub-sector has on one occasion only a significant effect on economic performance, which is negative. This seems to indicate, that sub-sector influences are likely of lesser relevance.

A negative coefficient for the "Mixed" sub-sector dummy means that firms in these two subsectors have lower returns on sales than firms in the "Cultural" sub-sector, all other things being equal. In order to interpret this effect it has to be remembered, that the "Mixed" subsector was defined as including those firms, which produce at least two types of paper of the three basic types cultural papers, industrial papers and other papers (e.g. tissue). The basic technological unit of a paper firm (and in this sense a better measure of production technology then the proxies used here based on sub-sector classification) is the individual paper machine. One paper machine can only produce one type of paper in the short term. Therefore, firms in the "Mixed" sub-sector must have at least two different paper machines producing at least two different types of papers. This observation can be the basis for explaining why firms in the "Mixed" sub-sector have significantly worse economic performance than firms operating in one highly profitable sub-sector. One argument can be that firms in the "Mixed" sub-sector cannot realise economies of scale to the same degree as can firms in the other sub-sectors since they have fewer or smaller paper machines for one product. This is purely an effect of production economics, to which the analysis reported here is limited. ${ }^{10}$ A related argument here is that the use of different production technologies only allows lower production outputs and therefore does not allow benefiting from economies of scale, which are significant in the paper manufacturing industry (Zavatta 1993).

\footnotetext{
${ }^{10}$ It would however be desirable in future research to also analyse the effect of the "Mixed" sub-sector on environmental performance resulting from sub-sector membership having a simultaneous effect on both, economic and environmental performance. For example, environmental performance could be lower, ceteris paribus, if firms have smaller and more customised operations as is likely the case in the "Mixed" sub-sector, where individual production runs consequently may have higher environmental impacts associated with them.
} 
As a result of the findings for the country dummy variables in the models estimated in the previous section of this paper, it can be concluded, that if there is a significant difference, firms located in the United Kingdom perform better relative to firms located in Germany. For ROS and the input-based index, firms located in Italy and the Netherlands as well perform relatively better than firms located in Germany in the relevant model (pooled model).

The main research question of this paper was about the relationship between environmental and economic performance and whether a firm's choice of a specific strategy towards sustainability and the environment has a significant effect on it. Strategies were differentiated in terms of pollution prevention (which can be considered, as argued at the end of the previous section an Environmental Shareholder Value (ESV) oriented strategy) and end-ofpipe (which cannot be seen as an ESV-oriented strategy). The analysis shows that in environmentally intensive industries such as paper manufacturing, it may be difficult to bring about a positive relationship but that is made easier through a focus on integrated pollution prevention (as a special case of an ESV-oriented strategy). This is evidence in favour of hypothesis $\mathrm{H} 2$ of the Introduction and also confirmation, that for firms with a pollution prevention strategy (and thus a strong ESV orientation) the relationship is more positive. Since the ESV concept links to the corporate environmental management activities pursued by a company it can also help managers to improve the relationship between environmental and economic performance. The confirmation of this proposition is of particular importance to practising managers.

The management consequences from this are that an end-of-pipe strategy (leading to improvements mainly in the undesired outputs of production processes, such as emissions to air and water but not many efficiency improvements) result in little positive or even negative effects of environmental performance improvements on economic performance (as was found in the empirical analysis). Therefore, a strategy based on end-of-pipe activities alone should be avoided by management. This finding of the analysis, which indicates that corporate strategies with regard to sustainability and the environment have an important moderating effect on the relationship between environmental and economic performance carries considerable weight for the practical significance of the results of this research. As concerns the implications for future research from this paper, it should be noted that (i) the approach can be extended to various other industry sectors (as e.g. is done in Wagner (2003) for the electricity supply industry) and that (ii) there are indications that the internal (e.g. strategy choice) and external (e.g. market structure) factors influencing the relationship between environmental and economic performance carry different weight in different industries, thus suggesting a situational or contingency approach in future research on this subject. In addition 
to that, based on the findings reported in this paper, future research needs to take into account more the moderating effect of strategy choices, than has been done to date. In addition to that, future research also needs to account more for potential endogeneity of the relationship between environmental and economic performance and strategy choice as well as other factors (see e.g. Al-Tuwaijri et al. (2004) for application simultaneous equations models to the relationship of environmental and economic performance) and the failure of this study to do so due to data restrictions has to be acknowledged as one of its limitations.

\section{Acknowledgements}

I would like to thank three anonymous reviewers for their very helpful comments and suggestions. Valuable comments from Joachim Wagner (University of Lüneburg), Théophile Azomahou and Phu Nguyen Van (University of Strasbourg) as well as Walter Wehrmeyer (University of Surrey) are gratefully acknowledged. Also I would like to thank my colleagues at the Centre for Sustainability Management, University of Lüneburg for providing input during various seminars. Funding for part of this research was provided under the European Commission Environment and Climate Research, contract no. ENV4-CT97-0655.

\section{References}

Al-Tuwaijri, S. A., Christensen, T. E., and Hughes II, K. E. (2004). The Relations among Environmental Disclosure, Environmental Performance, and Economic Performance: A Simultaneous Equations Approach. Accounting, Organizations and Society, 29.5-6, 447-471.

Belzer, P. (2000). Written personal communication provided by Ms. Petra Belzer, Sales Manager, Bureau van Dijk. Frankfurt, $31^{\text {st }}$ October 2000.

Behmanesh, N., Roque, J. A., and Allen, D. T. (1993). An Analysis of Normalized Measures of Pollution Prevention. Pollution Prevention Review, Spring, 161-166.

Berkhout, F., Hertin, J., Tyteca, D., Carlens, J., Olsthoorn, X., van Druinen, M., van der Woerd, F., Azzone, G., Noci, G., Jasch, C., Wehrmeyer, W., Wagner, M., Gameson, T., Wolf, O., and Eames, M. (2001). MEPI - Measuring Environmental Performance of Industry, final report and appendices submitted to the European Commission DG XII. Brussels: EC.

Confederation of the European Paper Industry (CEPI) (1998). CEPI Annual Statistics 1997. Brussels: Confederation of the European Paper Industry.

Blacconiere, W. and Patten, D. (1994). Environmental Disclosures, Regulatory Costs, and Changes in Firm Value. Journal of Accounting and Economics, 18, 357-377. 
Cohen, M.A., Fenn, S.A., and Naimon, J. (1995). Environmental and Financial Performance: Are they related? Nashville: Vanderbilt University, Owen Graduate School of Management. Cormier, D. and Magnan, M. (1997). Investors' Assessment of Implicit Environmental Liabilities: An Empirical Investigation. Journal of Accounting and Public Policy, 16, 215-241. Cormier, D., Magnan, M., and Morard, B. (1993). The Impact of Corporate Pollution on Market Valuation: Some Empirical Evidence. Ecological Economics, 8, 135-155.

Edwards, D. (1998). The Link between Company Environmental and Financial Performance. London: Earthscan.

Hart, S. L. and Ahuja, G. (1996). Does it Pay to be Green? An Empirical Examination of the Relationship between Emission Reduction and Firm Performance. Business Strategy and the Environment, 5, 30-37.

Jaggi, B. and Freedman, M. (1992). An Examination of the Impact of Pollution Performance on Economic and Market Performance of Pulp and Paper Firms. Journal of Business Finance \& Accounting, 19.5, 697-713.

Johnson, S. D. (1996). Environmental Performance Evaluation: Prioritizing Environmental Performance Objectives. Corporate Environmental Strategy, Autumn, 17-28.

Johnston, J. and DiNardo, J. (1997). Econometric Methods. (4 ${ }^{\text {th }}$ ed.). New York: McGrawHill.

King, A. and Lenox, M. (2000). Does it Really Pay to be Green? Journal of Industrial Ecology, 5.1, 105-116.

Kohler, U. and Kreuter, F. (2001). Datenanalyse mit Stata: allgemeine Konzepte der Datenanalyse und ihre praktische Anwendung (Data analysis with Stata: general concepts of data analysis and their practical application). Munich: Oldenbourg.

Konar, S. And Cohen, M. A. (2001). Does the Market Value Environmental Performance? Review of Economics and Statistics, 83.2, 281-289.

Lankoski, L. (2000). Determinants of Environmental Profit. Helsinki: University of Technology.

Olsthoorn, X., Tyteca, D., Wehrmeyer, W. and Wagner, M. (2001). Using Environmental Indicators for Business - A Literature Review and the Need for Standardisation and Aggregation of Data. Journal of Cleaner Production, 9.5, 453-463.

Porter, M. (1991). America's Green Strategy. Scientific American, 264.4, 96.

Rudestam, K. E., and Newton, R. R. (1992). Surviving your Dissertation: A Comprehensive Guide to Content and Process. Newbury Park, CA: Sage. 
Russo, M. V. and Fouts, P. A. (1997). A Resource-Based Perspective on Corporate Environmental Performance and Profitability. Academy of Management Journal, 40, 534-559. Schaltegger, S. (1988). Marktwirtschaftliche Instrumente des Umweltschutzes. Prüfung von Einsatzmöglichkeiten in der Region Basel (Market-based instruments of environmental protection. Assessment of possibilities of application in the Basle region). Basle: Center of Economics and Business Administration, Basle University.

Schaltegger, S., and Figge, F. (1998). Environmental Shareholder Value (Sarasin Basic Report Nr. 54). Basle: Sarasin/Center of Economics and Business Administration, Basle University.

Schaltegger, S. and Synnestvedt, T. (2002). The Link Between „Green“ and Economic Success. Environmental Management as the Crucial Trigger between Environmental and Economic Performance. Journal of Environmental Management, 65, 339-346. StataCorp (1997). Stata Statistical Software: Release 5.0. College Station, TX, Stata Corp. Wagner, J. (1998). Bestimmungsgründe internationaler Firmentätigkeit - Ergebnisse ökonometrischer Untersuchungen mit Daten aus niedersächsischen Industriebetrieben (Determinants of international firm activities - results of econometric analyses with data from industrial entreprises in Lower Saxony). Jahrbücher für Nationalökonomie und Statistik, 217, 613627.

Wagner, M. (2000). The Relationship between Environmental and Economic Performance of Firms. Paper presented at the $2^{\text {nd }}$ POSTI meeting in collaboration with the ESST Annual Scientific Conference. Strasbourg: BETA, Université Louis Pasteur, 27-28 May 2000. Accessible at: http://www.esst.uio.no/posti/workshops/wagner.html

Wagner, M. (2001). A Review of Empirical Studies concerning the Relationship between Environmental and Economic Performance of Firms: What does the Evidence tell us? Lueneburg: University of Lueneburg, Centre for Sustainability Management.

Wagner, M. (2003). Does it Pay to be Eco-Efficient in the European Electricity Supply Industry? Zeitschrift für Energiewirtschaft, 27.4, 309-318.

Zavatta, R. (1993). The Pulp and Paper Industry, in: de Jong, H. W. (ed.) The Structure of European Industry. ( $3^{\text {rd }}$ rev. ed., pp. 91-119). Dordrecht: Kluwer Academic Publishers. Ziegler, A., Rennings, K. \& Schröder, M. (2002). Der Einfluss ökologischer und sozialer Nachhaltigkeit auf den Shareholder Value europäischer Aktiengesellschaften (The influence of ecological and social sustainability on the shareholder value of European stock-listed companies). Mannheim: Center for European Economic Research (ZEW). 